\title{
Investimentos em previdência privada fechada: uma análise comparativa com outras opções de aplicações financeiras no Brasil
}

Namilton Nei Alves Coelho

Mestre em Administração pela Faculdade Novos Horizontes, FNH, Brasil

nncoelho@uol.com.br

\author{
Marcos Antônio de Camargos \\ DDoutor e Mestre em Administração pela UFMG \\ Pesquisador e Professor Adjunto de Finanças \\ Faculdade IBMEC-MG \\ marcosac@ibmecmg.br
}

\author{
Contextus \\ ISSNe 2178-9258 (ISSN 1678-2089) \\ Organização: Comitê Científico Interinstitucional \\ Editor Científico: José Carlos Lázaro \\ Avaliação: Double Blind Review pelo SEER/OJS \\ Revisão: Gramatical, normativa e de formatação \\ Recebido em 29.09.2009 \\ Aprovação Final em 20.08.2012
}

\section{RESUMO:}

A questão financeira é um dos aspectos fundamentais a serem considerados no planejamento da aposentadoria, na perspectiva de se manter ou melhorar as condições de vida nesse período "pós-laboral", diante da potencial limitação do sistema brasileiro de previdência social. O objetivo deste trabalho é analisar opções de aplicações financeiras disponíveis nas quatro maiores instituições financeiras do país, no período de 2005 a 2008 , visando verificar se as aplicações na previdência privada fechada proporcionaram retornos maiores comparativamente a essas opções. Na pesquisa empírica empreendida neste trabalho, caracterizada como descritiva e quantitativa, foram utilizados a Análise de Variância ou ANOVA (Analysis of Variance) e o "teste-t" com o intuito de examinar se as médias desses grupos analisados são estatisticamente diferentes entre si. Os resultados indicaram que as maiores rentabilidades acumuladas foram apresentadas pelos planos de previdência privada fechada, administrados por um fundo de pensão. Assim, o investidor deve estar atento aos diversos aspectos inerentes às aplicações disponíveis no mercado, observando as taxas de administração e de carregamento e outros produtos "embutidos", que podem, no longo prazo, afetar a rentabilidade e, consequentemente, comprometer a formação de reservas financeiras.

Palavras-chave: Previdência Complementar. Aposentadoria. PGBL. VGBL. Fundo de Pensão.

\begin{abstract}
This paper aims to analyze financial investments available in the four largest financial institutions in the Brazil, in the period from 2005 to 2008, to identify whether the applications in pension fund plan provided higher returns compared to those options. In the empirical research, characterized by being descriptive and quantitative, we used the Analysis of Variance (ANOVA) and the "t-test" to verify whether the means of these groups are analyzed statistically different. The results indicated that the highest cumulative returns were presented by the pension fund plans. Thus, the investor must be aware of the various aspects related to the applications available in the market, paying attention to management fees, loading and other products "embedded" that can, in the long run, affect the profitability and hence the formation of financial reserves.
\end{abstract}

Keywords: Social Security. Retirement. PGBL. VGBL. Pension Fund. 


\section{INTRODUÇÃO}

A previdência privada tem sido um importante instrumento utilizado pelas pessoas que estão em plena capacidade produtiva e que buscam produzir e acumular recursos financeiros capazes de propiciar uma aposentadoria com menores transtornos, em termos de renda e de qualidade de vida. O sistema público de concessão de aposentadoria tem se mostrado insuficiente para garantir o poder de compra dos aposentados, de modo a mantê-los nas mesmas condições socioeconômicas de antes.

De acordo com Cazassa (2002), as reformas na previdência social acabam por delinear mais limitações para a obtenção de benefícios, com tetos cada vez menores, passando, assim, a previdência complementar a ser considerada como uma necessidade básica. Necessidade essa que se fundamenta na perda do valor real dos benefícios concedidos pelo Instituto Nacional do Seguro Social (INSS), ante os hábitos de consumo das famílias, os quais tendem a não ser cobertos financeiramente somente pela aposentadoria pública. Nesse sentido, Cazassa (2002) aponta, ainda, a necessidade de uma reflexão, por parte da sociedade, sobre como planejar essa poupança preventiva (previdência complementar).

Dados de reconhecidos institutos de pesquisa e estatística indicam que o poder de compra da aposentadoria concedida pelo INSS tem apresentado uma expressiva perda para aqueles aposentados que recebem mais de um salário mínimo. No período de 1997 a 2007, o salário mínimo acumulou um reajuste de $239 \%$, enquanto os benefícios com valor maior do que o salário mínimo tiveram um reajuste de $112 \%$. Descontando-se a inflação acumulada nesse mesmo período, medida pelo IGP-M/FGV e pelo INPC/IBGE, esses reajustes apresentaram ganhos reais de $22,33 \%$ e $66,22 \%$, respectivamente, para aqueles que receberam um salário mínimo de aposentadoria. Já para aqueles que receberam mais de um salário mínimo, houve uma perda real de 23,5\% (considerando a inflação medida pelo IGP-M) e um ganho real de 3,95\% (considerando a inflação medida pelo INPC). Assim, a identificação de uma aplicação financeira que propicie retornos financeiros esperados deve ser feita com muito critério, tendo como referência estudos técnicos que ajudem nessa escolha.
A preocupação das pessoas reside numa questão primordial de que as despesas pessoais, a partir da aposentadoria, podem ser maiores do que aquelas praticadas na época de vida laboral, especialmente aquelas relacionadas com a saúde. De acordo com Pereira (2008), o envelhecimento da população, com o aumento da demanda de assistência médico-hospitalar, levanta preocupações no que concerne à gestão, oferta e demanda dos serviços de saúde pública e privada. Camargos (2004), por meio de um estudo realizado em 2000, com 2.142 idosos (60 anos ou mais) da cidade de São Paulo, observa que do grupo de 60 a 64 anos para o de 85 anos e mais, a prevalência de dependência física aumentou aproximadamente 11 vezes entre as mulheres e sete vezes entre os homens. Essa dependência se refere a algum grau de dificuldade apresentado pelos indivíduos na realização de tarefas cotidianas. Por certo, os gastos, nessas condições, podem se mostrar representativos, levando uma pessoa à dificuldade financeira, na hipótese de não se ter uma aposentadoria (pública ou privada) em patamares compatíveis com tais necessidades.

Assim, o planejamento da aposentadoria leva em conta aspectos do ponto de vista financeiro a fim de que esse suporte financeiro possa, de alguma forma, melhorar as condições de vida nesse período "pós-laboral". Nesse contexto, o objetivo deste trabalho é analisar algumas opções de aplicações financeiras (fundos de renda fixa, fundos de renda variável e planos de previdência aberta) disponíveis nas quatro maiores instituições financeiras do país, visando verificar se as aplicações na previdência privada fechada (fundos de pensão) proporcionaram retornos maiores comparativamente a essas opções. Com base comparativa, parte-se da premissa de que a rentabilidade acumulada no período de análise (2005 a 2008) pelos planos de previdência privada fechada, devido às suas características, seja superior ao rendimento das demais modalidades de aplicações financeiras.

Este artigo está estruturado em cinco partes: após esta introdução, na seção 2, expõe-se o referencial teórico sobre a previdência social, retratando alguns problemas enfrentados pelo sistema público de previdência no Brasil. Comenta-se sobre os regimes de previdência privada, destacando os modelos de planos de previdência 
disponibilizados pelas entidades abertas e fechadas de previdência complementar, além de fazer breves comentários sobre o sistema financeiro nacional. $\mathrm{Na}$ seção 3, é apresentada a metodologia. $\mathrm{Na} 4$, apontam-se os resultados e respectiva análise. Na seção 5 apresentase a conclusão, seguida das referências.

\section{REFERENCIAL TEÓRICO}

\subsection{O Sistema Público de Previdência no Brasil}

A formação do sistema público de previdência social no Brasil iniciou-se em 1933, com a criação do Instituto de Aposentadoria e Pensões dos Marítimos (IAPM). A partir daí, foram montados diversos Institutos de Aposentadorias e Pensões (IAPs), que progressivamente suplantariam as Caixas de Aposentadorias e Pensões (CAPs). Essas Caixas de Aposentadorias e Pensões foram criadas em 1923, pela Lei $n^{\circ} 4.062$, como organismos privados, centrados em empresas, objetivando assegurar a concessão de aposentadorias, pensões e assistência médica aos ferroviários. O financiamento das CAPs se dava por meio de contribuições de empresas, de empregados e do Estado. A administração era feita por conselhos de empregadores e empregados. Após 1930, ao longo dos primeiros anos do Governo Provisório, a regulação estatal sobre as CAPs se acentuou e estendeuas a empresas que empregavam outras categorias profissionais. Foi com a criação dos IAPs, entretanto, que se incrementou a incorporação dos trabalhadores brasileiros à previdência social. Com esses institutos, substituiu-se a organização por empresa pela proteção aos assalariados de uma mesma categoria profissional. Porém os benefícios cobertos por cada Instituto não eram uniformes, sendo determinante a força das categorias profissionais que cada um cobria, com acentuação do crescimento do controle estatal, principalmente em relação à aplicação dos recursos financeiros (DELGADO, 2001).

A partir de 1945, a instalação de estruturas de bem-estar social tornou-se uma dimensão importante do consenso keynesiano - e dos formatos institucionais a ele associados - promovido pelas instâncias reguladoras internacionais, em face das sequelas da Segunda Guerra Mundial e da ameaça representada pela expansão do "campo socialista" e das forças políticas de esquerda (DELGADO, 2001). O Estado do bem-estar é evidenciado no artigo $6^{\circ}$ da Constituição Federal brasileira de 1988, que assegura os direitos à saúde, à educação, ao trabalho, à moradia, ao lazer, à segurança, à previdência social, à proteção à maternidade e à infância, à assistência aos desamparados. Os artigos 193 e 204, da referida Constituição, abordam o Estado Democrático de Direito, assegurando os direitos relativos à Seguridade Social, cujo custeio é realizado com a participação de todos, trabalhadores e empregadores, sob o princípio da solidariedade (CARVALHO; MURGEL, 2007).

De acordo com Gacitúa-Marió e Woolcock (2005), saúde e previdência são componentes importantes e básicos da rede de proteção dos sistemas de bem-estar social. As fontes de receita da previdência social são, basicamente: recursos sobre a folha de salários (parte do empregador e do empregado), repasses da união e outras receitas patrimoniais e de aplicações financeiras (OLIVEIRA, BELTRÃO e DAVID, 1998). Essas contribuições feitas para a Seguridade Social têm o caráter de tributo; logo, existem contribuições sociais com a natureza jurídica de tributo (WEINTRAUB, 2005). Atualmente, a previdência social confere cobertura que substitui os rendimentos da ativa, em sua integralidade, somente aos trabalhadores de baixa renda. Para a chamada classe média, a previdência social não permite que os beneficiários mantenham o padrão de vida na velhice. Assim, uma grande parcela da população experimenta uma redução de remuneração ao se aposentar, considerando que o valor da aposentadoria pela previdência social é definido, no máximo, pelo valor do teto de contribuição, o qual a partir de 01/03/2008, passou para $\mathrm{R} \$ 3.038,99$, conforme Portaria Interministerial $n^{\circ} 77 / 2008$, publicada no Diário Oficial da União em 12/03/2008. Na prática, é difícil se atingir esse valor de aposentadoria, haja vista que ela é obtida pela média das contribuições feitas desde meados de 1994.

Segundo Gacitúa-Mario e Woolcock (2005), dada a inviabilidade financeira do sistema previdenciário atual, é inevitável que alterações futuras nesse sistema impliquem sempre na redução de benefícios e no aumento da idade 
de aposentadoria. Nos anos 90, a situação da previdência social brasileira se agravou e os constantes déficits, associados a um histórico quadro de desigualdades e diferenças de direitos e regras, se tornaram temas recorrentes na agenda político-econômica do país (ZYLBERSTAJN, AFONSO e SOUZA, 2006). Esses autores afirmam, também, que, considerando uma série de razões históricas e institucionais, mesmo com as reformas recentes, o sistema previdenciário

brasileiro ainda está longe de alcançar o equilíbrio atuarial, o incentivo à formalização e a redução das alíquotas de contribuição. O déficit da previdência social ainda pode ser compreendido pela relação entre contribuintes e beneficiários, uma vez que em 1950 essa relação era de oito contribuintes para cada beneficiário, passando para 1,7 contribuinte em 1997 (CARVALHO; MURGEL, 2007). A maneira de financiamento do regime de previdência social é um dos maiores problemas enfrentados por diversos países, e mudanças demográficas vêm ameaçando essa capacidade de financiamento. Estudos indicam que o sistema de previdência social americano e o de outros países europeus, além do Japão, deverão enfrentar problemas de financiamento até o ano de 2030, e que o equacionamento adequado da questão previdenciária é um dos pilares para a organização das contas públicas (ELLERY JR. e BUGARIN, 2003; AFONSO e FERNANDES, 2005).

A estrutura geral do sistema de previdência no Brasil é composta de três pilares:

1. Regime Geral de Previdência Social: público, com filiação obrigatória para os trabalhadores regidos pela Consolidação das Leis do Trabalho (CLT); operado pelo INSS com regime financeiro de caixa.

2. Regime de Previdência Complementar: privado, de natureza contratual, com filiação facultativa, autônomo em relação ao Regime Geral de Previdência Social e aos regimes próprios dos servidores públicos; operado por instituições financeiras com regime financeiro de capitalização.
3. Regime Próprio de Previdência dos Servidores: público, com filiação obrigatória para os servidores públicos titulares de cargos efetivos da União, dos Estados, do Distrito Federal e dos Municípios; operado sob o regime financeiro de caixa.

Estudos conduzidos por Ellery Jr. e Bugarin (2003) apontam que aproximadamente $15 \%$ de contribuição sobre a folha de pagamento seriam capazes de financiar um regime de aposentadoria integral, e que, no caso da economia brasileira, existe uma contribuição média de $22 \%$ sobre a folha de pagamento, paga pelas empresas, e mais $10 \%$ pagos pelos empregados, mas o caixa do INSS ainda se encontra em déficit. Entre as razões para tal déficit podem ser citadas: 1) incorporação de programas de assistência social no caixa da previdência, notadamente após a Constituição Federal de 1988; 2) média de idade de aposentadoria dos brasileiros relativamente baixa, o que onera o sistema. No caso de existir um sistema de previdência social, esse deveria repor, no máximo, 30\% do salário dos indivíduos, quando ativos, uma vez que um regime de participação que garanta aposentadoria integral, ou taxas de reposição muito altas, gera uma perda de bem-estar em relação a sistemas de capitalização pura (ELLERY JR. e BUGARIN, 2003; AFONSO e FERNANDES, 2005).

Com o objetivo de mostrar o impacto do tempo de contribuição na formação de reservas num período anterior à aposentadoria, Penna e Moraes (2001) projetaram um fundo capitalizado somente com contribuições de um empregado. Esse modelo indicou que, quando o tempo de acumulação de reservas cai de 40 para 30 anos, a contribuição mensal relativa quase dobra (acima de 82\%), considerada uma taxa de juros de 6\% ao ano. Assim, para receber uma importância mensal equivalente ao salário de contribuição, por um período de aposentadoria de 30 anos, um trabalhador deveria contribuir com 7,7\% do seu salário mensal durante 40 anos. Caso esse trabalhador contribua por somente 30 anos, em vez de 40, a contribuição mensal sobre o salário deverá ser elevada para 14,2\%. Esses cálculos consideram 12 contribuições mensais, apesar do desconto previdenciário também incidir sobre o $13^{\circ}$ salário. Outro fundamento utilizado pelos autores foi o de que tais 
contribuições seriam depositadas num fundo particular, como se fosse uma aplicação financeira exclusiva do respectivo contribuinte, sem a adição de contribuições do empregador.

Outro dado que ajuda a entender por que o atual sistema de previdência pública tende a arcar com valores de aposentadoria cada vez menores é o comportamento demográfico da massa da população brasileira. Levando em conta que o regime financeiro da previdência pública do Brasil é o de repartição, ou seja, um grupo de pessoas na ativa contribui para o pagamento daquelas que já estão aposentadas, uma relevante questão relacionada à mudança na composição demográfica do Brasil é a taxa de fecundidade, que retrata o número de filhos por mulher. De acordo com a Pesquisa Nacional por Amostra de Domicílios - PNAD (a pesquisa faz levantamentos socioeconômicos anuais da população brasileira, coletando dados em 147.851 domicílios de 851 municípios), referente ao ano de 2007, realizada pelo IBGE e divulgada em setembro/2008, constatouse um decréscimo na taxa de fecundidade total do país, chegando a 1,95, em 2007, ficando abaixo do nível de reposição da população - que é de 2,1 filhos por mulher.

\subsection{Previdência Privada no Brasil}

O ano de 1904 é um marco inicial da previdência privada no Brasil, época em que foi fundada a Caixa Montepio dos Funcionários do Banco do Brasil, precursora da atual Caixa de Previdência dos Funcionários do Banco do Brasil - PREVI (AFONSO, 1996). A institucionalização dos regimes de previdência privada no Brasil se deu, com mais efetividade, com a regulamentação por legislação específica (Lei no 6.435, de 15/07/1977). As instituições criadas pela iniciativa privada, inspiradas no mecanismo da previdência social, vieram satisfazer aos anseios de segurança que não poderiam ser atendidos pela previdência, razão pela qual, no Brasil, foram inicialmente denominadas entidades de "previdência privada". Atualmente, a denominação usual é “previdência complementar". A Lei no 6.435/77 dividiu a previdência privada em dois campos: previdência complementar fechada (Decreto $\mathrm{n}^{\circ}$ 81.240, de 20/01/1978) e previdência complementar aberta (Decreto $n^{\circ} 81.402$, de 23/02/1978). Até o ano de 2001, a base legal da previdência complementar no Brasil era composta por esses três diplomas normativos. Atualmente, essas entidades são regidas pela Lei Complementar $n^{\circ} 109$, de 29/05/2001 (BRASIL, 2001a). A Lei Complementar $n^{\circ}$ 108/2001 (BRASIL 2001b)regulamenta a relação entre União, Estados, Distrito Federal, Municípios, suas autarquias, fundações, sociedades de economia mista e outras entidades públicas e suas respectivas entidades fechadas de previdência complementar. (CARVALHO e MURGEL, 2007)

As entidades fechadas de previdência complementar (EFPC) têm as suas atividades enquadradas na área de competência do Ministério da Previdência e Assistência Social. As entidades abertas de previdência complementar (EAPC) são enquadradas na área de competência do Ministério da Fazenda, por intermédio da Superintendência Nacional de Seguros Privados (SUSEP).

A distinção entre os dois grupos de previdência complementar, aberta e fechada, está: a) no fato de a SUSEP ter a obrigatoriedade de vínculo empregatício entre o participante e a empresa patrocinadora do fundo ou, então, de vínculo associativo entre o participante e a entidade de classe instituidora do fundo (associação, cooperativa, sindicato, ou outra); b) no fato de não ter finalidade de lucro e; c) na universalidade da oferta do plano de benefícios, que obrigatoriamente deve ser oferecido a todos os empregados, associados ou membros da patrocinadora (CARVALHO e MURGEL, 2007).

Assim, a análise do papel das EFPCs está relacionada à política social, representada pelos aspectos previdenciários, com previsão na ordem social do diploma legal em vigor no país (PINHEIRO, 2005). Os fundos de pensão, como são conhecidas as EFPCs, apesar de interagirem fortemente com o mercado financeiro, como investidores institucionais, não se caracterizam como instituições financeiras, mesmo diante das diversas formatações jurídicas que possuem em diversos países (REIS, 2008).

A tributação do Imposto de Renda - IR, em relação à 
previdência privada no Brasil, tem atualmente, uma natureza de postergação de imposto, ou seja, durante a fase de acumulação de recursos há a possibilidade de isenção de IR, mas quando do recebimento de benefícios aplica-se o imposto. Esse tratamento fiscal está baseado em premissas como: incentivar a adesão de pessoas ao setor, promover o almejado equilíbrio social decorrente da manutenção do padrão econômico na aposentadoria e assegurar que a fonte de arrecadação tributária não sofra diminuição (GAUDENZI, 2008). A legislação permite que as contribuições feitas, em favor de dependentes e do responsável, limitadas a $12 \%$ da remuneração desse responsável, em planos de previdência privada, podem ser deduzidas na declaração de Imposto de Renda. O mencionado limite de dedução de até $12 \%$ não poderá ser aproveitado, na prática, para os contribuintes que fazem a declaração anual de Imposto de Renda pelo modelo simplificado, em que o desconto padrão é de $20 \%$ englobando todos os possíveis descontos e abatimentos na base de cálculo do imposto de renda.

Quando do recebimento do benefício ou resgate, há dois regimes de tributação do Imposto de Renda, pelos quais os participantes de planos de previdência podem optar: 1) tabela progressiva: os resgates de reservas ou recebimento de benefícios são tributados pela mesma tabela de IR que tributa o salário da pessoa física no Brasil; 2) tabela regressiva: a alíquota de incidência do IR é reduzida a cada dois anos, chegando a $10 \%$ para contribuições feitas há mais de 10 anos. A escolha de um ou outro regime dependerá do planejamento de renda futura de cada participante. Na hipótese de se efetuar resgate da reserva do plano de previdência privada num curto prazo, a tabela progressiva apresenta alíquotas de IR menores, uma vez que na tabela regressiva as reservas acumuladas e resgatadas, num prazo inferior a quatro anos, são tributadas pela alíquota do IR de 30\%. Na progressiva, a alíquota poderá ser entre $0 \%$ e $27,5 \%$, dependendo do valor a ser resgatado. É importante destacar que a opção por um ou outro regime de tributação é irretratável, motivo pelo qual é necessária uma cuidadosa análise no momento da escolha, quando da entrada no plano.

No caso da previdência privada fechada, os planos de benefícios de caráter previdenciário são normatizados pela Resolução do Conselho de Gestão de Previdência Complementar - CGPC n ${ }^{\circ} 16$, de 22 de novembro de 2005. Tal Resolução prevê a existência de três planos: 1) benefício definido - BD: os benefícios programados têm seu valor ou nível previamente estabelecidos, sendo o custeio determinado atuarialmente, de forma a assegurar sua concessão e manutenção; 2) contribuição definida CD: criados na década de 80 (CONDE e ERNANDES, 2007), os benefícios são programados, tendo seu valor permanentemente ajustado ao saldo de conta mantido em favor do participante. Diferentemente do plano BD, o valor final a ser recebido quando da aposentadoria dependerá diretamente dos valores aportados para o plano CD; 3) contribuição variável - CV: conjugação das características das modalidades de contribuição definida e benefício definido.

Os fundos de previdência complementar, sejam abertos ou fechados, têm os recursos financeiros mantidos em aplicações do mercado financeiro. Ou seja, eles são fundos de investimento com gestão própria ou de instituições financeiras, que contam com profissionais conhecedores do mercado financeiro e suas diferentes modalidades de aplicações. Há de se considerar que quanto maiores forem os juros pagos na renda fixa, decorrentes da taxa de juros paga pelo governo, menor será a tendência dos fundos de pensão em direcionar recursos em renda variável (SCHMITT, 2004). Em face das quedas que vêm sendo verificadas nas taxas de juros reais no Brasil, Saad (2007) argumenta que as aplicações do patrimônio dos produtos de previdência em renda variável devem crescer. Os ativos dos fundos de pensão totalizaram em abril/2008 R \$ 456,56 bilhões, o que representa 17,8\% do Produto Interno Bruto - PIB brasileiro (anualizado no período do $2^{\circ}$ tri/2007 ao $1^{\circ}$ tri/2008 - R \$ 2,6 trilhões), e pagam, mensalmente, $\mathrm{R} \$ 2,5$ bilhões em aposentadorias e pensões, em valores entre cinco e oito vezes superiores aos da previdência social pública (PIMENTEL, 2007). Em países como o Brasil, os fundos de pensão também podem contribuir para a diluição da propriedade, o aumento da eficiência do mercado de capitais e a criação de mecanismos de financiamentos que poderão ser utilizados por diversas empresas para sustentar seus investimentos (RABELO, 1998). 
Com o intuito de avaliar o retorno real das carteiras de ações dos fundos de pensão brasileiros, no período de 1999 a março/2001, Amaral et al. (2004) utilizaram o Capital Asset Pricing Model - CAPM (modelo que estabelece as relações de risco e retorno esperado para verificar se um determinado título está sendo negociado dentro de seu preço justo), o Índice de Sharpe (razão entre o prêmio pelo risco da carteira e o seu desvio padrão, medindo a remuneração obtida por unidade de exposição ao risco) e o Índice de Franco Modigliani e Leah Modigliani (Índice M2, cujo objetivo é medir o excesso de retorno do fundo em relação ao retorno de mercado, se ambos tivessem a mesma volatilidade, mostrando quanto um fundo ganha ou perde, em relação ao mercado, quando os riscos são equivalentes). A conclusão foi que, de forma geral, os retornos reais superaram os retornos estimados, e os fundos de pensão alcançaram remuneração pelo risco superior ao do mercado. Os autores afirmam que os resultados encontrados podem ser aplicados ao período de 2002/2003, uma vez que as carteiras dos fundos de pensão permaneceram com uma composição similar às carteiras pesquisadas no período analisado.

Os planos oferecidos pela previdência aberta são normatizados pela SUSEP por meio das Resoluções do Conselho Nacional de Seguros Privados - CNS: 92/2002, $124 / 2005$ e 125/2005. Os planos mais conhecidos são o Plano Gerador de Benefícios Livres - PGBL e o Vida Gerador de Benefícios Livres - VGBL. A diferença básica é que no VGBL não há previsão de dedução de até $12 \%$ da remuneração da pessoa física para efeitos de Imposto de Renda, conforme previsto nos planos PGBL. Entretanto, por não serem isentas as contribuições para o VGBL durante o prazo de constituição das reservas financeiras, essa isenção do IR será concedida na fase de recebimento do benefício, excetuando-se os ganhos provenientes da aplicação financeira. O VGBL se torna interessante, sob o ponto de tributário, quando a pessoa faz a declaração anual de Imposto de Renda simplificada, ou quando a pessoa possui um PGBL e deseja aplicar mais do que $12 \%$ de sua remuneração em planos de previdência. Nesse último caso, a pessoa faz um PGBL com aplicações de até $12 \%$ de sua remuneração e destina o excedente a um VGBL (WEINTRAUB, 2008). Dados divulgados pela SUSEP indicam que as contribuições na previdência privada aberta brasileira em 2007, envolvendo todos os planos, totalizaram R \$ 7,93 bilhões, revelando uma concentração de recursos em companhias relacionadas aos bancos Bradesco, Banco do Brasil, Itaú e Unibanco, que juntos representam 68,9\% ( $R \$ 5,47$ bilhões).

\section{Ativos Financeiros, Risco e Retorno}

O mercado financeiro desempenha função essencial para o desenvolvimento de um país, ao canalizar recursos de agentes superavitários (poupadores) para agentes deficitários (tomadores de recursos) na economia. Para efetivar essa intermediação, existem instituições chamadas de intermediários financeiros, exemplificadas por bancos e corretores de ações. Dessa forma, as pessoas, as empresas e o governo podem se utilizar do mercado financeiro para ajustar sua poupança e seu consumo por meio de operações de tomada ou concessão de recursos via empréstimos (ROSS, WESTERFIELD, JAFFE, 2002).

O sistema financeiro pode ser entendido como o conjunto de instrumentos, mecanismos e instituições que asseguram a canalização da poupança para o investimento. Esse investimento caracteriza uma origem de um setor com recursos que deseja "emprestar" a outro setor, a uma determinada taxa de juros, levando em consideração os riscos envolvidos em cada operação. Para fazer essa intermediação, os operadores do sistema financeiro devem oferecer, por um lado, produtos que satisfaçam às exigências de remuneração, prazos, risco e retorno dos poupadores nas aplicações do excedente de recursos, e, por outro lado, condições de crédito com custos acessíveis e prazos compatíveis com as necessidades dos tomadores de recursos.

Os ativos financeiros são títulos disponíveis no mercado para aplicação de recursos, a saber: 1) de renda fixa: garantem a devolução do capital investido inicialmente, mais uma remuneração (juros) que pode ser periódica (com pagamento de cupons) ou não (pagamento dos juros e do principal no momento do resgate). Podem ser: prefixados, pós-fixados ou indexados; 2) de renda variável: não garantem a devolução do capital investido inicialmente e nem remuneração no período da aplicação. 
Dessa forma, a exposição do investidor ao risco é bem maior nestes últimos ativos, fato que faz com que seja exigido, em contrapartida, um patamar de risco maior.

Qualquer aplicação realizada no mercado financeiro apresenta vantagens e desvantagens, além de determinado nível de risco, que deve ser compatível com o retorno que oferece. Assim, nas decisões de investimento é essencial que se conheça o risco de determinada aplicação, de modo a avaliar se a rentabilidade proposta compensa a exposição ao risco. O risco de um ativo tem dois componentes: 1) o risco específico (diversificável): pode ser eliminado por meio de investimentos em vários ativos, baseado na premissa de que quanto maior for a concentração de recursos num só tipo de aplicação maior tende a ser o risco do aplicador, caso haja algum problema com esse fundo; 2) o risco de mercado, conhecido por sistemático (não diversificável): não pode ser eliminado, independe do nível de diversificação procedido, pois é oriundo de fatores macroeconômicos que afetam todas as empresas e seus ativos (de maneira diferenciada). Portanto, o risco de uma carteira bem diversificada é avaliado pelo nível de risco de mercado dos títulos incluídos nessa carteira (BREALEY, MYERS, 2006).

\section{METODOLOGIA}

A pesquisa empírica empreendida neste trabalho caracteriza-se como descritiva e quantitativa, e teve por objetivo analisar opções de aplicações financeiras (fundos de renda fixa, fundos de renda variável e planos de previdência aberta) disponíveis nas quatro maiores instituições financeiras do país, visando verificar se as aplicações na previdência privada fechada (fundos de pensão) proporcionaram retornos maiores comparativamente a essas opções. Na operacionalização da pesquisa, após a revisão teórica sobre a previdência pública e a previdência complementar no Brasil, foram identificadas as principais opções de aplicações financeiras no país, com as suas composições de ativos. Posteriormente, foram levantados dados secundários, por meio de visitas nas quatro maiores instituições financeiras que atuam no mercado brasileiro, no segmento de fundos de investimento (Banco do Brasil, Itaú-Unibanco, Bradesco e Caixa Econômica Federal), conforme Tabela 1. Essas visitas tiveram por objetivo levantar as rentabilidades obtidas no período de 2000 a 2008 de aplicações de renda fixa e variável, de maior volume de aplicações, oferecidas por essas quatro instituições financeiras.

Tabela 1 - Participação dos Bancos no Segmento de Fundos

de Investimento no Mercado Brasileiro - Março/2009

\begin{tabular}{|c|c|c|}
\hline BANCO & $\begin{array}{c}\text { PATRIMÔNIO } \\
\text { (Em R\$/bilhões) }\end{array}$ & $\begin{array}{c}\text { \% do } \\
\text { Mercado }\end{array}$ \\
\hline Banco do Brasil & 280.045 & 24,6 \\
\hline Itaú-Unibanco & 196.061 & 17,2 \\
\hline Bradesco & 154.810 & 13,6 \\
\hline $\begin{array}{c}\text { Caixa Econômica } \\
\text { Federal }\end{array}$ & 86.668 & 7,6 \\
\hline Total & $\mathbf{7 1 7 . 5 8 4}$ & $\mathbf{6 3 , 0}$ \\
\hline Total do Mercado & 1.138 .407 & \\
\hline
\end{tabular}

Fonte - Adaptada pelos autores de Pavini (2009, p-D1).

Foram pesquisadas também, as rentabilidades apresentadas por cinco planos de previdência privada fechada, administrados por um fundo de pensão brasileiro, localizado em São Paulo/SP, no período de 2000 a 2008. A etapa posterior do desenvolvimento desta pesquisa foi a comparação das rentabilidades apresentadas, objetivando examinar os resultados e possíveis vantagens daquelas atinentes à previdência privada fechada.

A amostra de pesquisa é não probabilística, selecionada com base na facilidade de acesso aos dados secundários das quatro instituições financeiras e dos cinco planos de previdência, administrados por um fundo de pensão.

As aplicações selecionadas das instituições financeiras atenderam aos seguintes critérios de escolha: 1) aplicação disponível a qualquer pessoa física; 2) no caso da modalidade de renda fixa, três aplicações com aportes iniciais de cerca de $\mathrm{R} \$ 1.000,00 ; \mathrm{R} \$ 5.000,00$ e $\mathrm{R} \$$ 10.000,00. A escolha desses montantes se fez necessária tendo em vista que as taxas de administração praticadas nas instituições financeiras variam, principalmente, de acordo com o aporte inicial. Considerando que as instituições financeiras pesquisadas possuem aportes iniciais diversos, foram selecionados aqueles que mais 
se aproximavam dos três parâmetros citados. Assim, a demonstração desses níveis de aportes iniciais foi ajustada, objetivando facilitar a compreensão deste estudo, já que esse ajuste não distorceu, de forma relevante, os montantes reais requeridos em cada instituição; 3) no caso das aplicações em previdência aberta, três tipos de modalidade em cada instituição financeira: a) uma que tivesse uma carteira totalmente composta por títulos de renda fixa; b) uma que tivesse uma carteira composta por títulos de renda fixa e de renda variável, na seguinte proporção: $85 \%$ em renda fixa e $15 \%$ em renda variável; c) uma que tivesse uma carteira composta por títulos de renda fixa e de renda variável, na seguinte proporção: $70 \%$ em renda fixa e $30 \%$ em renda variável. Assim, a única modalidade igual para as instituições pesquisadas foi a composta somente por títulos de renda fixa.

Após a identificação desses investimentos, estabeleceramse parâmetros de modalidades de aplicações possíveis de comparação entre as instituições. Além das aplicações financeiras, foram obtidos dados referentes às modalidades de previdência privada aberta vinculadas às respectivas instituições financeiras. Os dados pesquisados são referentes ao período de 2000 a 2008, apesar de algumas modalidades não apresentarem rentabilidades para todo esse período. Essas restrições de períodos se deram em função de algumas modalidades de aplicações terem iniciado após 2000, ou de não haver disponibilidade de dados por parte da instituição financeira.

Os dados dos cinco planos de previdência privada, administrados por um fundo de pensão, levam em consideração as rentabilidades mensais do período de 2000 a 2008. Esses planos possuem diferenças na constituição da carteira de investimentos, em termos de montantes aplicados em renda fixa e em renda variável. Essa diversidade possibilita a comparação com outras modalidades de aplicações financeiras constantes do presente estudo.

As comparações foram feitas por meio da divisão da rentabilidade obtida no período, em número-índice, pelo percentual acumulado em cada variável de comparação, tomando-se por base o mesmo período. O resultado dessa equação significa a variação percentual de cada modalidade de investimento em relação à respectiva variável. Por exemplo, o índice de 15,36\%, constante da $1^{\text {a }}$ coluna da Tabela 2 , significa que a rentabilidade acumulada pelo Banco 1 foi $15,36 \%$ superior à rentabilidade da Caderneta de Poupança no mesmo período, e assim sucessivamente.

Os dados foram coletados e tabulados no Microsoft Excel. Para a comparação de rentabilidade entre aplicações financeiras e planos de previdência, foi utilizada a Análise de Variância ou ANOVA (Analysis of Variance), que se trata de um procedimento muito utilizado em comparações entre grupos amostrais, realizado por meio de um teste de hipóteses de médias de dois ou mais grupos. O objetivo da ANOVA é verificar se as médias desses grupos analisados são estatisticamente diferentes entre si, sendo possível utilizar essa análise para abordar várias questões, de forma simultânea. Uma vez constatadas diferenças entre médias de grupos pela ANOVA, utilizouse o "teste-t" para duas amostras presumindo variâncias diferentes, visando identificar quais apresentavam médias estatisticamente diferentes entre si (FREUND e SIMON, 2000).

Com o objetivo de dispor de mais fatores de comparação das rentabilidades das aplicações financeiras, foram utilizados quatro benchmarks de mercado: Caderneta de Poupança, Certificado de Depósito Interbancário - CDI e os índices IGPM/FGV e INPC/IBGE. Ressalte-se que o CDI foi utilizado por ser referência de comparação em aplicações de renda fixa, já que esse título é restrito ao mercado interbancário.

Para comparar resultados desses benchmarks com aqueles apresentados por planos de previdência privada fechada (Planos A, B, C e E), administrados por um fundo de pensão, foram consideradas características semelhantes, de acordo com o Quadro 1. O Plano A possui características passíveis de comparação com as modalidades de aplicações dos bancos nos Níveis 1,2 e 3 , além da previdência privada renda fixa dessas instituições. Os Planos C e E são comparáveis à modalidade de previdência privada RV 15. O Plano B serviu de comparação com a previdência privada RV 30. Dessa forma, somente os bancos de números 
1 e 4, dos analisados, apresentaram modalidades de aplicações financeiras compatíveis com os planos de previdência fechada, nas modalidades RV 15 e RV 30, conforme dados constantes das tabelas 7 e 8 . Em relação ao Plano D (previdência privada fechada), não foram encontradas modalidades de aplicações financeiras, nos bancos pesquisados, que pudessem servir de comparação. Portanto, os dados do Plano D não constam das análises deste artigo

Quadro 1 - Modalidades de aplicações x parâmetros de comparação

\begin{tabular}{|c|c|}
\hline \hline Modalidades de aplicações & $\begin{array}{c}\text { Parâmetro de çomparação } \\
\text { previdência privada fechada }\end{array}$ \\
\hline Renda Fixa Nível 1 & Plano A \\
\hline Renda Fixa Nível 2 & Plano A \\
\hline Renda Fixa Nível 3 & Plano A \\
\hline Previdência Privada Renda Fixa & Plano A \\
\hline Previdência Privada RV 15 & Planos Ce E \\
\hline Previdência Privada RV 30 & Plano B \\
\hline
\end{tabular}

Fonte - Elaborado pelos autores.

O Quadro 2 apresenta as características de cada modalidade de aplicação, levando-se em consideração as exigências dos bancos: valor mínimo de aplicação requerido; saldo mínimo e aplicações mínimas adicionais.

Quadro 2 - Características das Modalidades de Aplicações

\begin{tabular}{|c|c|}
\hline $\begin{array}{c}\text { Modalidades de } \\
\text { aplicações }\end{array}$ & Características \\
\hline Renda Fixa Nível 1 & $\begin{array}{l}\text { Exigência de capital inicial entre } \mathrm{R} \$ 100,00 \text { e } \mathrm{R} \$ 1.000,00 \text {; } \\
\text { aportes mensais mínimos de } \mathrm{R} \$ 1,00 \text { a } \mathrm{R} \$ 100,00 \text {; taxas de } \\
\text { administração entre } 2,0 \% \text { e } 3,5 \% \text { ao ano. }\end{array}$ \\
\hline Renda Fixa Nível 2 & $\begin{array}{c}\text { Exigência de capital inicial entre } \mathrm{R} \$ 5.000,00 \text { e } \mathrm{R} \$ \\
10.000,00 \text {; aportes mensais mínimos de } \mathrm{R} \$ 1,00 \text { a } \mathrm{R} \$ \\
500,00 \text {; taxas de administração entre } 1,5 \% \text { e } 2,5 \% \text { ao ano. }\end{array}$ \\
\hline Renda Fixa Nível 3 & $\begin{array}{l}\text { Exigência de capital inicial entre } \mathrm{R} \$ 5.000,00 \text { e } \mathrm{R} \$ \\
\text { 40.000,00; aportes mensais mínimos de R } \$ 1,00 \text { a R } \$ \\
500,00 \text {; taxas de administração entre } 1,0 \% \text { e } 1,5 \% \text { ao ano. }\end{array}$ \\
\hline $\begin{array}{l}\text { Previdência Privada } \\
\text { Renda Fixa }\end{array}$ & $\begin{array}{c}\text { Não há exigência de aporte inicial; valores mínimos } \\
\text { mensais entre R\$ } 50,00 \text { e R } \$ 250,00 \text {; taxas: de } \\
\text { administração (incide sobre o total aplicado), variando } \\
\text { entre } 1,5 \% \text { e } 3,0 \% \text { e de carregamento (incide sobre os } \\
\text { aportes mensais), variando entre } 0 \% \text { e } 5,0 \% \text {. }\end{array}$ \\
\hline $\begin{array}{l}\text { Previdência Privada } \\
\text { RV } 15\end{array}$ & $\begin{array}{l}\text { Não há exigência de aporte inicial; valores mínimos } \\
\text { mensais entre R } \$ 50,00 \text { e R } \$ 250,00 \text {; taxas: de } \\
\text { administração (incide sobre o total aplicado), oscilando } \\
\text { entre } 1,5 \% \text { e } 3,0 \% \text {, e de carregamento (incide sobre os } \\
\text { aportes mensais), oscilando entre } 0 \% \text { e } 5,0 \% \text {; os ativos } \\
\text { estão aplicados em renda fixa e renda variável, nas } \\
\text { proporções de } 85 \% \text { e } 15 \% \text {, respectivamente. }\end{array}$ \\
\hline $\begin{array}{l}\text { Previdência Privada } \\
\text { RV } 30\end{array}$ & $\begin{array}{l}\text { Não há exigência de aporte inicial; valores mínimos } \\
\text { mensais entre R } \$ 50,00 \text { e R } \$ 250,00 \text {; taxas: de } \\
\text { administração (incide sobre o total aplicado), variando } \\
\text { entre } 1,5 \% \text { e } 3,0 \% \text {, e de carregamento (incide sobre os } \\
\text { aportes mensais), variando entre } 0 \% \text { e } 5,0 \% \text {; os ativos } \\
\text { estão aplicados em renda fixa e renda variável, nas } \\
\text { proporções de } 70 \% \text { e } 30 \% \text {, respectivamente. }\end{array}$ \\
\hline
\end{tabular}

A hipótese de pesquisa testada neste estudo foi:

H0 - o retorno médio das aplicações financeiras é igual ao retorno médio dos planos de previdência fechada selecionados.

A ideia era refutar essa hipótese visando encontrar evidências de diferenças entre médias (nível de significância de 5\%) ou indícios (nível de significância de $10 \%)$.

\section{ANÁLISE DE RESULTADOS}

Objetivando sistematizar a apresentação dos dados, optou-se por analisá-los de acordo com os diversos níveis de aplicações disponíveis nos quatro bancos pesquisados e compará-los com os resultados dos planos de previdência privada fechada. Considerando que o Plano A é referência para as modalidades de renda fixa níveis 1,2 e 3 , além da previdência privada renda fixa disponibilizada pelos bancos pesquisados, os resultados comparativos aos índices da Caderneta de Poupança, CDI, IGP-M e INPC são idênticos nessas modalidades.

Tendo em vista a necessidade de se ter períodos e parâmetros de comparação idênticos, e, após a análise de todas as médias mensais obtidas, foi possível comparar os resultados do período de 2005 a 2008, exceto na análise da modalidade Previdência Privada RV - 30, cujo período foi de 2004 a 2007. A justificativa dessa exceção consta do referido tópico.

\section{Renda Fixa Nível 1}

Os dados constantes da Tabela 2 indicam que, no período de janeiro/2005 a dezembro/2008, o Plano A apresentou uma rentabilidade acumulada de 64,43\%, mostrando-se a melhor quando comparada com as demais opções. Comparando essa rentabilidade com outros índices (variáveis externas), no mesmo período, constata-se que ela foi $19,66 \%$ superior à rentabilidade da poupança; $32,24 \%$ e $35,97 \%$ superiores ao IGP-M e ao INPC, respectivamente, indicando ganhos reais em relação a esses índices inflacionários. Em relação ao CDI, a rentabilidade do Plano A foi 4,41\% menor, apesar de todas as demais opções apresentarem rentabilidades ainda menores quando comparadas ao CDI. A segunda melhor rentabilidade apresentada nessa modalidade 
foi a do Banco 1, com 58,51\%, seguida pelo Banco 3 (52,44\%), Banco 2 (52,03\%) e Banco 4 (50,38\%). A diferença entre a maior rentabilidade acumulada (Plano A) e a menor rentabilidade acumulada (Banco 4) foi de $9,34 \%$, indicando que, caso uma pessoa tivesse recursos aplicados no Plano A, as reservas financeiras seriam superiores, ao final do período analisado, em 9,34\% em relação àquelas verificadas se esses recursos estivessem aplicados no Banco 4. Ressalte-se que essas rentabilidades não consideram a tributação do Imposto de Renda, tendo em vista que a forma de tributação, na previdência privada, pode se dar por meio das tabelas progressiva ou regressiva, conforme mencionado anteriormente.

Tabela 2 - Renda Fixa Nível 1 - Resultados Comparativos (em \%)

\begin{tabular}{|l|c|c|c|c|c|}
\hline & \multicolumn{4}{|c|}{ BANCOS } & \\
\cline { 2 - 6 } & 1 & 2 & 3 & 4 & Plano A \\
\hline Rentabilidade Acumulada & 58,51 & 52,03 & 52,44 & 50,38 & 64,43 \\
\hline Rentabilidade Média & 0,97 & 0,88 & 0,88 & 0,85 & 1,04 \\
\hline Erro-padrão & 0,08 & 0,05 & 0,03 & 0,04 & 0,07 \\
\hline Desvio-padrão & 0,55 & 0,34 & 0,24 & 0,25 & 0,47 \\
\hline Variância da amostra & 0,30 & 0,11 & 0,06 & 0,06 & 0,22 \\
\hline
\end{tabular}

Comparação da Rentabilidade Acumulada em relação a variáveis

\begin{tabular}{|c|c|c|c|c|c|}
\hline Variável & $\mathbf{1}$ & $\mathbf{2}$ & $\mathbf{3}$ & $\mathbf{4}$ & Plano A \\
\hline Poupança & 15,36 & 10,64 & 10,94 & 9,44 & 19,66 \\
\hline CDI & $-7,85$ & $-11,62$ & $-11,38$ & $-12,57$ & $-4,41$ \\
\hline IGP-M & 27,48 & 22,27 & 22,60 & 20,94 & 32,24 \\
\hline INPC & 31,08 & 25,72 & 26,06 & 24,35 & 35,97 \\
\hline Fonte - Elaborado pelos autores.
\end{tabular}

\section{Renda Fixa Nível 2}

Em relação à modalidade Renda Fixa Nível 1, nota-se que as taxas de administração apresentadas pelo Renda Fixa Nível 2 são inferiores, sendo exigido nessa modalidade um aporte inicial maior. Dessa forma, esse aporte inicial maior pode ser um limitador de acesso, pois nem todas as pessoas interessadas em investir dispõem desse capital inicial. Nessa análise não foi considerado o Banco 3 , tendo em vista que os dados disponíveis para essa modalidade abrangem somente o período de jan/2006 a dez/2008, enquanto os demais são de jan/2005 a $\operatorname{dez} / 2008$.
Os dados constantes da Tabela 3 indicam que o Plano A apresentou uma rentabilidade acumulada de 64,43\%, revelando-se a melhor quando comparada com as demais opções. Comparando essa rentabilidade com outros índices (variáveis externas), no mesmo período, verifica-se que ela foi $19,66 \%$ superior à rentabilidade da Caderneta de Poupança; 32,24\% e 35,97\% superiores ao IGP-M e ao INPC, respectivamente, indicando ganhos reais em relação a esses índices inflacionários. Em relação ao CDI, a rentabilidade do Plano A foi 4,41\% menor, apesar de todas as demais opções apresentarem rentabilidades ainda menores quando comparadas ao CDI. A segunda melhor rentabilidade apresentada nessa modalidade foi a do Banco 1, com 62,96\%, seguida pelo Banco 2 (60,87\%) e pelo Banco 4 (56,48\%). A diferença entre a maior rentabilidade acumulada (Plano A) e a menor rentabilidade acumulada (Banco 4) foi de 5,08\%. Destaca-se que as rentabilidades apresentadas pelos respectivos bancos são superiores àquelas registradas na análise da Renda Fixa Nível 1, possivelmente porque essa modalidade apresentou taxas de administração superiores.

Tabela 3 - Renda Fixa Nível 2 - Resultados Comparativos (em \%)

\begin{tabular}{|c|c|c|c|c|}
\hline & \multicolumn{3}{|c|}{ BANCOS } & \multirow[b]{2}{*}{ Plano A } \\
\hline & 1 & 2 & 4 & \\
\hline Rentabilidade Acumulada & 62,96 & 60,87 & 56,48 & 64,43 \\
\hline Rentabilidade Média & 1,02 & 1,00 & 0,94 & 1,04 \\
\hline Erro-padrão & 0,04 & 0,06 & 0,04 & 0,07 \\
\hline Desvio-padrão & 0,25 & 0,40 & 0,25 & 0,47 \\
\hline Variância da amostra & 0,06 & 0,16 & 0,06 & 0,22 \\
\hline \multicolumn{5}{|c|}{ Comparação da Rentabilidade Acumulada em relação a variáveis } \\
\hline Variável & 1 & 2 & 4 & Plano A \\
\hline Poupança & 18,59 & 17,07 & 13,88 & 19,66 \\
\hline CDI & $-5,26$ & $-6,48$ & $-9,03$ & $-4,41$ \\
\hline IGP-M & 31,06 & 29,38 & 25,85 & 32,24 \\
\hline INPC & 34,76 & 33,03 & 29,40 & 35,97 \\
\hline
\end{tabular}

Fonte-Elaborado pelos autores. 


\section{Renda Fixa Nível 3}

Em relação às modalidades Renda Fixa Nível 1 e Nível 2, as taxas de administração apresentadas pelo Renda Fixa Nível 3 são inferiores, sendo exigido nessa modalidade um aporte inicial maior. Daí, quanto maior é o aporte inicial menor é a taxa de administração. Assim, esse aporte inicial também pode ser um limitador de acesso, pois nem todas as pessoas interessadas em investir dispõem desse capital inicial.

Os dados constantes da Tabela 4 indicam que o Plano A apresentou uma rentabilidade acumulada de $64,43 \%$, distinguindo-se também como a melhor quando comparada com as demais opções. Comparando essa rentabilidade com outros índices (variáveis externas), no mesmo período, observa-se que a mesma foi $19,66 \%$ superior à rentabilidade da poupança; $32,24 \%$ e $35,97 \%$ superiores ao IGP-M e ao INPC, respectivamente, indicando ganhos reais em relação a esses índices inflacionários. Em relação ao CDI, a rentabilidade do Plano A foi $4,41 \%$ menor, apesar de todas as demais opções apresentarem rentabilidades ainda menores quando comparadas ao CDI. A segunda melhor rentabilidade apresentada nessa modalidade foi a do Banco 2, com $64,22 \%$, seguida pelo Banco 1 (63,85\%), Banco 4 (62,88\%) e Banco 3 (54,53\%). A diferença entre a maior rentabilidade acumulada (Plano A) e a menor rentabilidade acumulada (Banco 3) foi de $6,41 \%$. As rentabilidades apresentadas pelos respectivos bancos são superiores àquelas registradas nas análises das modalidades Renda Fixa Nível 1 e Nível 2, possivelmente porque aquelas modalidades apresentam taxas de administração superiores. Entretanto, a avaliação de rentabilidade somente pelo ponto de vista da taxa de administração pode não revelar o resultado real. $\mathrm{Na}$ presente modalidade, as taxas de administração dos Bancos 3 e 4 são iguais, porém as rentabilidades acumuladas são diferentes $(54,53 \%$ e $62,88 \%$, respectivamente).
Tabela 4 - Renda Fixa Nível 3 - Resultados Comparativos (em \%)

\begin{tabular}{|c|c|c|c|c|c|}
\hline \multicolumn{6}{|c|}{ BANCOS } \\
\hline & 1 & 2 & 3 & 4 & Plano A \\
\hline Rentabilidade Acumulada & 63,85 & 64,22 & 54,53 & 62,88 & 64,43 \\
\hline Rentabilidade Média & 1,03 & 1,04 & 0,92 & 1,02 & 1,04 \\
\hline Erro-padrão & 0,04 & 0,06 & 0,18 & 0,04 & 0,07 \\
\hline Desvio-padrão & 0,28 & 0,40 & 1,23 & 0,25 & 0,47 \\
\hline Variância da amostra & 0,08 & 0,16 & 1,51 & 0,06 & 0,22 \\
\hline \multicolumn{6}{|c|}{ Comparação da Rentabilidade Acumulada em relação a variáveis } \\
\hline Variável & 1 & 2 & 3 & 4 & Plano A \\
\hline Poupança & 19,24 & 19,51 & 12,46 & 18,54 & 19,66 \\
\hline CDI & $-4,74$ & $-4,53$ & $-10,16$ & $-5,31$ & $-4,41$ \\
\hline IGP-M & 31,78 & 32,07 & 24,28 & 31,00 & 32,24 \\
\hline INPC & 35,49 & 35,80 & 27,78 & 34,69 & 35,97 \\
\hline
\end{tabular}

Fonte - Elaborado pelos autores.

\section{Previdência Privada Renda Fixa}

Essa modalidade de aplicação financeira é comumente conhecida por previdência aberta, ou seja, aquela acessível a qualquer pessoa interessada. Esse tipo de previdência é oferecido por meio de agências bancárias. O que difere a previdência aberta da previdência fechada é que a última só é acessível a um grupo de pessoas ligadas a uma determinada empresa ou associação.

As taxas de carregamento são variáveis; enquanto o Banco 3 leva em consideração as contribuições mensais para definir o percentual dessa taxa, os demais bancos consideram os fundos acumulados. Nota-se que esses parâmetros para a cobrança da taxa de carregamento não são idênticos, mesmo entre aqueles bancos que consideram o fundo acumulado, o que, de certa forma, pode confundir uma análise superficial por parte de investidores interessados. Os chamados fundos de pensão, que administram planos fechados de previdência, cobram uma taxa de administração que incide sobre os aportes mensais. Essa taxa pode variar de um fundo para outro, e mesmo de um plano para outro, levandose em consideração a complexidade da formatação do plano (benefício definido, contribuição definida, plano misto) e a massa de participantes. As rentabilidades ora apresentadas são líquidas de taxas, tanto para a previdência aberta quanto para a fechada. No caso da previdência aberta, há as taxas de carregamento e de administração, enquanto no fundo de pensão a taxa incide somente sobre a contribuição mensal do participante. 
A análise de variância indicou, com significância de 10\%, que há indícios de que as médias dos grupos analisados eram diferentes, conforme Tabela 5. Após a realização do "teste t: duas amostras presumindo variâncias diferentes", para todos os dados analisados, conforme tabelas 6 e 6 A, constatou-se que essas diferenças eram entre: Banco 1 e Banco 3; Banco 2 e Banco 3; Banco 1 e Plano A. Dessa forma, para se identificar a "melhor" aplicação dessa modalidade, analisaram-se as médias e a rentabilidade acumulada.

Tabela 5 - Análise de Variância - Previdência Renda Fixa

\begin{tabular}{|cccccc|}
\hline \multicolumn{6}{|c|}{ Anova: fator único } \\
\hline \multicolumn{6}{cc}{ RESUM0 } \\
\hline Grupo & Obs. & Soma & Média & Variância \\
\hline 1 & 48 & 42,89 & 0,893542 & 0,084743 \\
2 & 48 & 41,87 & 0,872292 & 0,161337 \\
3 & 48 & 49,37 & 1,028542 & 0,068757 \\
4 & 48 & 43,96 & 0,915833 & 0,13385 \\
PLAN0 A & 48 & 50,04 & 1,0425 & 0,221466 \\
\hline \multicolumn{7}{c}{ ANOVA } \\
\hline Fonte da variação & SQ & gl & MQ & & F \\
\hline Entre grupos & 1,205619 & 4 & 0,301405 & 2,248775 & 0,064575 \\
Dentro dos grupos & 31,49721 & 235 & 0,134031 & & \\
Total & 32,70283 & 239 \\
\hline
\end{tabular}

Fonte - Elaborado pelos autores.

Tabela 6 - Teste-t: duas amostras presumindo variâncias diferentes

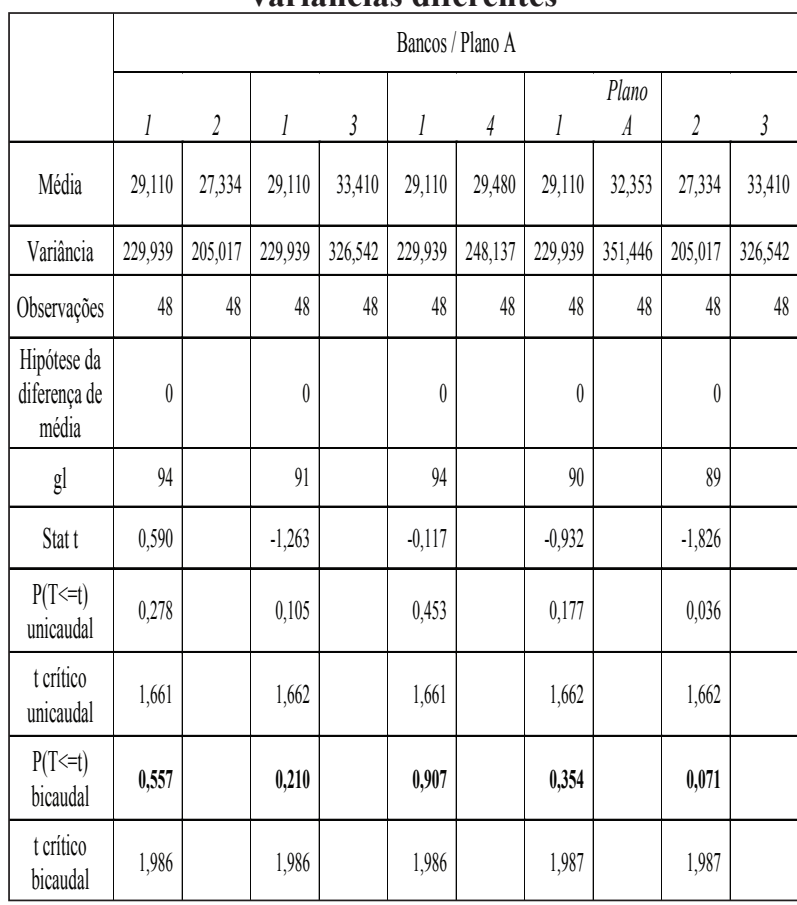

Fonte - Elaborada pelos autores. Continua 1/2
Tabela 6 A - Teste-t: duas amostras presumindo variâncias diferentes

\begin{tabular}{|c|c|c|c|c|c|c|c|c|c|c|}
\hline & \multicolumn{10}{|c|}{ Bancos / Plano A } \\
\hline & 2 & 4 & 2 & Plano A & 3 & 4 & 3 & Plano A & 4 & Plano A \\
\hline Média & 27,334 & 29,480 & 27,334 & 32,353 & 33,410 & 29,480 & 33,410 & 32,353 & 29,480 & 32,353 \\
\hline Variância & 205,017 & 248,137 & 205,017 & 351,446 & 326,542 & 248,137 & 326,542 & 351,446 & 248,137 & 351,446 \\
\hline Observaçōes & 48 & 48 & 48 & 48 & 48 & 48 & 48 & 48 & 48 & 48 \\
\hline $\begin{array}{c}\text { Hipótese da } \\
\text { diferença de } \\
\text { média }\end{array}$ & 0 & & 0 & & 0 & & 0 & & 0 & \\
\hline $\mathrm{gl}$ & 93 & & 88 & & 92 & & 94 & & 91 & \\
\hline Statt & $-0,698$ & & $-1,474$ & & 1,136 & & 0,281 & & $-0,813$ & \\
\hline $\begin{array}{l}\mathrm{P}(\mathrm{T}<=\mathrm{t}) \\
\text { unicaudal }\end{array}$ & 0,243 & & 0,072 & & 0,130 & & 0,390 & & 0,209 & \\
\hline $\begin{array}{l}\text { t crítico } \\
\text { unicaudal }\end{array}$ & 1,661 & & 1,662 & & 1,662 & & 1,661 & & 1,662 & \\
\hline $\begin{array}{l}\mathrm{P}(\mathrm{T}<=t) \\
\text { bicaudal }\end{array}$ & 0,487 & & 0,144 & & 0,259 & & 0,779 & & 0,419 & \\
\hline $\begin{array}{l}\text { t crítico } \\
\text { bicaudal }\end{array}$ & 1,986 & & 1,987 & & 1,986 & & 1,986 & & 1,986 & \\
\hline
\end{tabular}

Fonte - Elaborada pelos autores. Continuação 2/2.

Os dados constantes da Tabela 7 indicam que o Plano A apresentou uma rentabilidade acumulada de 64,43\% (rentabilidade média mensal de 1,04\%), mostrando-se também a melhor quando confrontada com as demais opções. Comparando essa rentabilidade com outros índices (variáveis externas), no mesmo período, percebe-se que ela foi $19,66 \%$ superior à rentabilidade da poupança; $32,24 \%$ e $35,97 \%$ superiores ao IGP-M e ao INPC, respectivamente, indicando ganhos reais em relação a esses índices inflacionários. Em relação ao CDI, a rentabilidade do Plano A foi 4,41\% menor, apesar de todas as demais opções apresentarem rentabilidades ainda menores quando comparadas ao CDI. A segunda melhor rentabilidade apresentada nessa modalidade foi a do Banco 3, com 63,4 $\%$, seguida pelo Banco 4 (54,85\%), Banco 1 (53,23\%) e Banco 2 (51,67\%). A diferença entre a maior rentabilidade acumulada (Plano A) e a menor rentabilidade acumulada (Banco 2) foi de 8,41\%. 
Tabela 7 - Previdência Renda Fixa - Resultados Comparativos

\begin{tabular}{|c|c|c|c|c|c|}
\hline & \multicolumn{4}{|c|}{ BANCOS } & \multirow[b]{2}{*}{ Plano A } \\
\hline & 1 & 2 & 3 & 4 & \\
\hline Rentabilidade Acumulada & 53,23 & 51,67 & 63,4 & 54,85 & 64,43 \\
\hline Rentabilidade Média & 0,89 & 0,87 & 1,03 & 0,92 & 1,04 \\
\hline Erro-padrão & 0,04 & 0,06 & 0,04 & 0,05 & 0,07 \\
\hline Desvio-padrão & 0,29 & 0,40 & 0,26 & 0,37 & 0,47 \\
\hline Variância da amostra & 0,08 & 0,16 & 0,07 & 0,13 & 0,22 \\
\hline \multicolumn{6}{|c|}{ Comparação da Rentabilidade Acumulada em relação a variáveis } \\
\hline Variável & 1 & 2 & 3 & 4 & Plano A \\
\hline Poupança & 11,51 & 10,38 & 18,91 & 12,69 & 19,66 \\
\hline CDI & $-10,92$ & $-11,82$ & $-5,01$ & $-9,98$ & $-4,41$ \\
\hline IGP-M & 23,23 & 21,98 & 31,41 & 24,54 & 32,24 \\
\hline INPC & 26,71 & 25,42 & 35,12 & 28,05 & 35,97 \\
\hline
\end{tabular}

Fonte - Elaborada pelos autores.

\section{Previdência Privada RV 15}

O percentual aplicado em renda variável (15\%) é entendido como um fator de incremento de rentabilidade global, pois no longo prazo espera-se que a renda variável apresente uma rentabilidade superior àquela da renda fixa. Em tese, quanto maior é o percentual destinado à renda variável, mais se busca aumentar a rentabilidade no longo prazo. Ocorre que a renda variável possui um risco maior do que a renda fixa, não sendo possível determinar, com segurança, a sua rentabilidade no curto ou no longo prazo.

Nessa modalidade, os aportes e as taxas de administração são idênticos aos expostos na modalidade anterior. Nesse caso, consideraram-se para análise os Bancos 1 e 4, haja vista que os demais não possuem a mesma composição de RV 15, composição importante, pois esse parâmetro é o mesmo dos Planos C e E. Os dados constantes da Tabela 8 indicam que os Planos $\mathrm{C}$ e E apresentaram, respectivamente, rentabilidades acumuladas de 73,12\% e 75,37\%. Essas rentabilidades foram superiores àquelas verificadas nos Bancos 1 (52,87\%) e 4 (59,95\%). Comparando as rentabilidades dos mencionados planos com outros índices (variáveis externas), no mesmo período, verifica-se que as mesmas foram superiores. Destaca-se o Plano E, com 27,63\% superior à rentabilidade da Caderneta de Poupança; 41,04\% e 45,02\% superiores ao IGP-M e ao INPC, respectivamente, indicando ganhos reais em relação a esses índices inflacionários; 1,95\% superior ao CDI. A diferença entre a maior rentabilidade acumulada (Plano E) e a menor rentabilidade acumulada (Banco 1) foi de $14,72 \%$, indicando que, caso uma pessoa tivesse recursos aplicados no Plano E, as reservas financeiras seriam superiores, ao final do período analisado, em 14,72\%.

\section{Tabela 8 - Previdência RV 15 - Resultados Comparativos (em \%)}

\begin{tabular}{|c|c|c|c|c|}
\hline & \multicolumn{2}{|c|}{ BANCOS } & \multirow[b]{2}{*}{ Plano C } & \multirow[b]{2}{*}{ Plano E } \\
\hline & 1 & 4 & & \\
\hline Rentabilidade Acumulada & 52,87 & 59,95 & 73,12 & 75,37 \\
\hline Rentabilidade Média & 0,89 & 0,99 & 1,16 & 1,19 \\
\hline Erro-padrão & 0,14 & 0,16 & 0,15 & 0,19 \\
\hline Desvio-padrão & 0,94 & 1,11 & 1,06 & 1,31 \\
\hline Variância da amostra & 0,89 & 1,24 & 1,13 & 1,70 \\
\hline \multicolumn{5}{|c|}{ Comparação da Rentabilidade Acumulada em relação a variáveis } \\
\hline Variável & 1 & 4 & Plano C & Plano E \\
\hline Poupança & 11,25 & 16,40 & 25,99 & 27,63 \\
\hline CDI & $-11,13$ & $-7,01$ & 0,65 & 1,95 \\
\hline IGP-M & 22,95 & 28,64 & 39,23 & 41,04 \\
\hline INPC & 26,41 & 32,27 & 43,16 & 45,02 \\
\hline
\end{tabular}

Fonte - Elaborada pelos autores.

\section{Previdência Privada RV 30}

No caso da RV 30 também se consideraram para análise os Bancos 1 e 4, já que os demais não possuem a mesma composição de RV 30, composição importante, pois esse parâmetro é o mesmo do Plano B, tornando possível a comparação. O período de comparação dessa modalidade difere daquele das demais modalidades, haja vista que a composição RV 30 do Plano B é até o ano de 2007. Para ter o mesmo número de meses das demais modalidades, considerou-se nessa modalidade o período de janeiro/2004 a dezembro/2007.

Os dados constantes da Tabela 9 indicam que o Plano $\mathrm{B}$ apresentou rentabilidade acumulada de 119,64\% 
(rentabilidade média mensal de 1,67\%), superior àquelas rentabilidades verificadas nos Bancos 1 (80,52\%) e 4 $(84,85 \%)$. Comparando a rentabilidade do mencionado Plano com outros índices (variáveis externas), no mesmo período, depreende-se que ela foi superior 59,52\% em relação à Caderneta de Poupança; 72,54\% e 82,21\% em relação ao IGP-M e ao INPC, respectivamente, indicando ganhos reais em relação a esses índices inflacionários; $23,52 \%$ em relação ao CDI. A diferença entre a maior rentabilidade acumulada (Plano B) e a menor rentabilidade acumulada (Banco 1) foi de 21,67\%.

Tabela 9 - Previdência RV 30 - Resultados Comparativos (em \%)

\begin{tabular}{|l|c|c|c|}
\hline \multirow{2}{*}{} & \multicolumn{2}{|c|}{ BANCOS } & \\
\cline { 2 - 4 } & $\mathbf{1}$ & $\mathbf{4}$ & Plano B \\
\hline Rentabilidade Acumulada & 80,52 & 84,85 & 119,64 \\
\hline Rentabilidade Média & 1,25 & 1,30 & 1,67 \\
\hline Erro-padrão & 0,20 & 0,25 & 0,28 \\
\hline Desvio-padrão & 1,41 & 1,76 & 1,96 \\
\hline Variância da amostra & 1,98 & 3,09 & 3,85 \\
\hline
\end{tabular}

Comparação da Rentabilidade Acumulada em relação a variáves

\begin{tabular}{|c|c|c|c|}
\hline Variável & $\mathbf{1}$ & $\mathbf{4}$ & Plano B \\
\hline Poupança & 31,11 & 34,25 & 59,52 \\
\hline CDI & 1,52 & 3,95 & 23,52 \\
\hline IGP-M & 41,81 & 45,21 & 72,54 \\
\hline INPC & 49,76 & 53,35 & 82,21 \\
\hline Obs.: período comparado - jan/2004 a dez/2007. \\
\hline
\end{tabular}

Fonte - Elaborada pelos autores.

Enfim, na análise das rentabilidades médias das modalidades de aplicações financeiras, por meio da ANOVA, conforme Tabela 10, foram encontrados indícios (significância de 10\%) de que as rentabilidades médias do grupo de Previdência Privada Renda Fixa são estatisticamente diferentes. Para os demais grupos não se tem indício e nem evidência estatística que indique diferenças entre eles. Em outras palavras, os grupos comparados têm, em média, a mesma rentabilidade, mas não quer dizer que eles sejam iguais.
Tabela 10 - Análise de Variância

\begin{tabular}{|c|c|c|c|c|c|c|c|}
\hline \multicolumn{8}{|c|}{ ANOVA: Fator Único } \\
\hline Grupo & Fonte da variação & $S Q$ & $g l$ & MQ & $F$ & P-Value & F crítico \\
\hline \multirow{3}{*}{$\begin{array}{l}\text { Renda Fixa } \\
\text { Nivel } 1\end{array}$} & Entre grupos & 1,1818 & 4 & 0,29545 & 1,9526327 & 0,1025501 & 2,4100578 \\
\hline & Dentro dos grupos & 35,55750625 & 235 & 0,1513085 & & & \\
\hline & Total & 36,73930625 & 239 & & & & \\
\hline \multirow{3}{*}{$\begin{array}{l}\text { Renda Fixa } \\
\text { Nivel } 2\end{array}$} & Entre grupos & 0,300075 & 3 & 0,100025 & 0,7820265 & 0,505329 & 2,6526456 \\
\hline & Dentro dos grupos & 24,04611667 & 188 & 0,1279049 & & & \\
\hline & Total & 24,34619167 & 191 & & & & \\
\hline \multirow{3}{*}{$\begin{array}{c}\text { Renda Fixa } \\
\text { Nivel } 3\end{array}$} & Entre grupos & 0,532764167 & 4 & 0,133191 & 0,3270294 & 0,859672 & 2,4100578 \\
\hline & Dentro dos grupos & 95,70973542 & 235 & 0,4072755 & & & \\
\hline & Total & 96,24249958 & 239 & & & & \\
\hline \multirow{3}{*}{$\begin{array}{l}\text { Previdência } \\
\text { Renda Fixa }\end{array}$} & Entre grupos & 1,205619167 & 4 & 0,3014048 & 2,2487746 & 0,064575 & 2,4100578 \\
\hline & Dentro dos grupos & 31,49721042 & 235 & 0,1340307 & & & \\
\hline & Total & 32,70282958 & 239 & & & & \\
\hline \multirow{3}{*}{$\begin{array}{c}\text { Previdência } \\
\text { RV } 15\end{array}$} & Entre grupos & 2,846279167 & 3 & 0,9487597 & 0,7645702 & 0,5152323 & 2,6526456 \\
\hline & Dentro dos grupos & 233,2903208 & 188 & 1,240906 & & & \\
\hline & Total & 236,1366 & 191 & & & & \\
\hline \multirow{3}{*}{$\begin{array}{c}\text { Previdência } \\
\text { RV } 30\end{array}$} & Entre grupos & 5,087593056 & 2 & 2,5437965 & 0,8561439 & 0,4269932 & 3,0602918 \\
\hline & Dentro dos grupos & 418,9428042 & 141 & 2,9712256 & & & \\
\hline & Total & 424,0303972 & 143 & & & & \\
\hline
\end{tabular}

Fonte - Elaborada pelos autores.

\section{CONCLUSÃO}

Destaca-se dar por meio das tabelas progressiva e/ou regressiva. Uma das explicações para esse desempenho da previdência fechada pode ser a justificativa de que ela não possui fins lucrativos, vertendo toda a rentabilidade das aplicações financeiras para os planos administrados. Já as instituições financeiras analisadas possuem fins lucrativos, sendo necessária a cobrança de taxas (de administração e de carregamento) que cubram os custos operacionais das empresas gestoras e ainda lhes garantam lucros.

Comparando-se somente as modalidades de aplicações em renda fixa, nos Níveis de 1 a 3, o Plano A apresentou a melhor rentabilidade acumulada, no período de janeiro/2005 a dezembro/2008, de 64,43\%, seguida pelo Banco 1 (64,22\% e 62,96\% nas modalidades Renda Fixa Níveis 3 e 2, respectivamente), e pelo Banco 4 (58,51\% na modalidade Renda Fixa Nível 1). As menores rentabilidades acumuladas nesses níveis foram: Banco 4 (50,38\% e 56,48\% Renda Fixa Níveis 1 e 2, respectivamente), Banco 3 (54,53\% Renda Fixa Nível 3).

Em relação à modalidade de previdência privada aberta e à previdência fechada, na modalidade renda fixa, o Plano A (previdência fechada) apresentou a melhor rentabilidade, 
com $64,43 \%$, seguida pela previdência aberta do Banco 3 (63,4\%). A menor rentabilidade nessa modalidade foi a do Banco 2 (51,67\%). Cabe destacar que as rentabilidades da previdência aberta, renda fixa, verificadas nos Bancos 1 e 2 são inferiores às respectivas rentabilidades desses bancos nas outras modalidades de renda fixa (níveis 1, 2 e 3). Nos Bancos 3 e 4 as rentabilidades da renda fixa (nível 3) são superiores às respectivas taxas desses bancos para essa modalidade de previdência. Analisando-se a previdência privada aberta com a previdência fechada, na modalidade RV 15, os Planos E e C (previdência fechada) apresentaram as melhores rentabilidades com $75,37 \%$ e $73,12 \%$, respectivamente, seguida pela previdência aberta do Banco 4 (59,95\%). A menor rentabilidade nessa modalidade foi a do Banco $1(52,87 \%)$. O melhor resultado da previdência privada aberta com a previdência fechada, na modalidade RV 30, foi verificado no Plano B (previdência fechada) com 119,64\%, seguido pela previdência aberta do Banco 4 $(84,85 \%)$. A menor rentabilidade nessa modalidade foi a do Banco $1(80,52 \%)$.

Assim, o investidor deve estar atento aos diversos aspectos inerentes às aplicações disponíveis no mercado, examinando as taxas de administração e de carregamento e outros produtos "embutidos" que podem, no longo prazo, afetar a rentabilidade e, consequentemente prejudicar a formação de reservas financeiras. Nesse aspecto, mesmo avaliando somente as rentabilidades dos quatro maiores bancos do país, constantes deste estudo, verificam-se importantes diferenças de rentabilidades acumuladas dentro de uma mesma modalidade de aplicação.

Como restrição ao presente estudo, pode-se citar a não disponibilização, por parte dos bancos pesquisados, de dados uniformes em todas as modalidades de aplicações, circunstância que não diminui a relevância deste estudo o qual levou em consideração as rentabilidades mensais dos últimos quatro anos.

Outros trabalhos nessa área podem ser direcionados a comparar rentabilidades de outros planos administrados por fundos de pensão com outras instituições financeiras do país, alternativamente àquelas ora analisadas. Também pode ser feita uma pesquisa de caráter qualitativo com investidores, pessoas físicas, objetivando conhecer quais são os principais motivos que os levam a direcionar recursos em determinado banco ou em certa modalidade de aplicação financeira, em se tratando de planejamento previdenciário.

\section{REFERÊNCIAS}

AFONSO, L. E. Previdência social e fundos de pensão. Rio de Janeiro: FUNENSEG, 1996.

AFONSO, L. E.; FERNANDES, R. Uma estimativa dos aspectos distributivos da previdência social no Brasil. RBE - Revista Brasileira de Economia. Rio de Janeiro, v. 59, p. 295-334, jul./set. 2005.

AMARAL, H. F.; VILAÇA, C. S. I.; BARBOSA, C. F. M.; BRESSAN, V. G. F. Fundos de pensão como formadores de poupança interna: uma alternativa para o financiamento da atividade econômica. RAC - Revista de Administração Contemporânea, v. 8, n. 2, p. $137-$ 158, abr./jun. 2004.

BRASIL. Ministério da Fazenda - Superintendência de Seguros Privados. Previdência aberta consumidor. Brasília: DF, 2008. Disponível em: <http://www. susep.gov.br/menuatendimento/previdencia aberta consumidor.asp\#defbas > . Acesso em: 03 set. 2008.

BRASIL. Ministério da Fazenda - Superintendência de Seguros Privados. Boletim estatístico dos mercados supervisionados. Brasília: DF, 2008. Disponível em: $<$ http://www.susep.gov.br/menuestatistica/estatisticas. asp>. Acesso em: 03 set. 2008

BRASIL. Portaria Interministerial $n^{0} 77 / 2008$. DOU, Brasília, 12 de março de 2008.

BRASIL. Presidência da República - Casa Civil Subchefia para Assuntos Jurídicos. Constituição da República Federativa do Brasil de 1988. DOU, Brasília, 5 de outubro de 1988. 
BRASIL. Presidência da República - Casa Civil Subchefia para Assuntos Jurídicos. Dispõe sobre as entidades de previdência privada. DOU, Brasília, 15 de julho de 1977. Revogada pela Lei Complementar $n^{\circ} 109$, de 29 de maio de 2001 .

BRASIL. Presidência da República - Casa Civil Subchefia para Assuntos Jurídicos. Dispõe sobre o Regime de Previdência Complementar e dá outras providências. DOU, Brasília, 29 de maio de 2001.

BRASIL. Presidência da República - Casa Civil Subchefia para Assuntos Jurídicos. Dispõe sobre a relação entre a União, os Estados, o Distrito Federal e os Municípios, suas autarquias, fundações, sociedades de economia mista e outras entidades públicas e suas respectivas entidades fechadas de previdência complementar, e dá outras providências. DOU, Brasília, 29 de maio de 2001.

BREALEY, R. A.; MYERS, S. C. Finanças corporativas: investimento de capital e avaliação. Tradução: Robert Brian Taylor. Porto Alegre: Bookman, 2006. 552 p.

CAMARGOS, M. C. S. Estimativas de expectativa de vida livre de e com incapacidade funcional: uma aplicação do método Sullivan para idosos paulistanos, 2000. 2004. 94 f. Dissertação (Mestrado em Demografia) - Universidade Federal de Minas Gerais, Belo Horizonte, 2004.

CARVAlHO, F. J.; MURGEL, M. I. Tributação de fundos de pensão. Belo Horizonte: Decálogo, 2007. 227 p.

CAZASSA, V. Os fundos de pensão na atualidade. 2002. 118 f. Dissertação (Mestrado Profissionalizante em Economia) - Universidade Federal do Rio Grande do Sul, Porto Alegre, 2002.

CONDE, N. C.; ERNANDES, I. S. Atuária para não atuários. São Paulo: ABRAPP/ICSS/SINDAP, 2007. $168 \mathrm{p}$.

DELGADO, I. G. Previdência social e mercado no
Brasil: a presença empresarial na trajetória da política social brasileira. São Paulo: LTr, 2001. 317 p.

ELLERY JR., R. G.; BUGARIN, M. N. S. Previdência social e bem estar no Brasil. RBE - Revista Brasileira de Economia. Rio de Janeiro, v. 57, p. 27-57, jan./mar. 2003.

FREUND, J. E.; SIMON, G. A. Estatística aplicada: economia, administração e contabilidade; trad. Alfredo Alves de Farias. Porto Alegre: Bookman, 2000. 404 p.

GACITÚA-MARIÓ, E.; WOOLCOCK, M. (Org.). Exclusão social e mobilidade no Brasil. Brasília: IPEA: Banco Mundial, 2005. 306 p.

GAUDENZI, P. B. L. Tributação dos investimentos em previdência complementar privada. São Paulo: Quartier Latin, 2008. 302 p.

PROJEÇÃO POPULAÇÃO BRASIL - 2050. In: INSTITUTO BRASILEIRO DE GEOGRAFIA E ESTATÍSTICA - IBGE. Banco de dados. Disponível em: <http://www.ibge.gov.br/home/estatistica/populacao/ projecao da populacao/default.shtm $>$. Acesso em: 18 set. 2008 .

OLIVEIRA, F.; BELTRÃO, K.; DAVID, A. Previdência, poupança e crescimento econômico: interações e perspectivas. Rio de Janeiro: IPEA, 1998.

PAVINI, A. Alta concentração: onda de fusões de bancos deixa o setor de fundos cada vez mais restritos a poucas instituições. Jornal Valor Econômico, São Paulo, 19 mai.2009, Eu \& Investimentos, p. D-1.

PENNA, A. F. S.; MORAES, M. A. S. Um modelo quantitativo de um fundo de capitalização. Revista de Administração. São Paulo, v. 36, n. 1, p. 46-56, jan./mar. 2001 .

PEREIRA, N. T. D. S. O programa "Envelhecer com Saúde" como instrumento de marketing de relacionamento em uma operadora de planos de saúde. 2008. 111 f. Dissertação (Mestrado em Administração) Faculdade Novos Horizontes, Belo Horizonte, 2008.

PIMENTEL, F. O papel social dos fundos de pensão. 
In: GÓES, W. (org.). Papel dos fundos de pensão na formação da economia brasileira. São Paulo: ABRAPP/ ICSS/SINDAPP, 2007.

PINHEIRO, R. P. Riscos demográficos e atuariais nos planos de benefício definido e de contribuição definida num fundo de pensão. 2005. 296 f. Tese (Doutorado em Demografia) - Universidade Federal de Minas Gerais, Belo Horizonte, 2005.

RABELO, F. M. Fundos de pensão, mercado de capitais e corporate governance: lições para os mercados emergentes. RAE - Revista de Administração de Empresas. São Paulo, v. 38, n. 1, p. 38-51, jan./mar. 1998.

REIS, A. A regulação internacional dos investimentos dos fundos de pensão. In: REIS, A. (org.). Fundos de pensão e mercado de capitais. São Paulo: Peixoto Neto, 2008. $239 \mathrm{p}$

ROSS, S. A.; WESTERFIELD, R. W.; JAFFE, J. F. Administração financeira: corporate finance. São Paulo: Atlas, 2002.

SAAD, N. S. Proposta de modelos de apreçamento de opções embutidas em produtos de previdência no Brasil. 2007. 112 f. Dissertação (Mestrado em Engenharia) - Universidade de São Paulo, São Paulo, 2007.

SCHMITT, R. R. K. Desenvolvimento de um modelo de Balanced Scorecard para uma entidade fechada de previdência complementar. 2004. 127 f. Dissertação (Mestrado Profissionalizante em Economia com ênfase em Controladoria) - Universidade Federal do Rio Grande do Sul, Porto Alegre, 2004.

WEINTRAUB, A. B. V. Previdência privada: doutrina e jurisprudência. São Paulo: Quartier Latin, 2005. 334 p.

ZYLBERSTAJN, H.; AFONSO, L. E.; SOUZA, A. P. Reforma da previdência social e custo de transição: simulando um sistema universal para o Brasil. Revista de Contabilidade e Finanças da USP. São Paulo: especial atuária, Dez. 2006: 56-74. 